\title{
Water pollution legislation in Iran vs England and Wales
}

\author{
G. Asadollahfardi \\ Department of Civil Engineering, Faculty of Engineering, \\ Tarbiyat Moalem University, Tehran, Iran
}

\begin{abstract}
In order to control water pollution in a more effective way, there is a need to set up legislation which will cover all aspects relating to water pollution. The second step would be the implementation and management of that legislation in order to achieve the most effective result. Despite three decades of existing legislation and management for water pollution control in Iran, the results of implementation are still not effective. Hence, it is vital to identify the problems which cause improper improvement in surface and ground water quality. First a review of some historical trends of water pollution legislation and management is presented, which have been in progress since the start of legislation in Iran, as well as in England and Wales. Then a comparison of current legislation in both countries is made and also the implementation of the legislation is explained. The results indicate an imbalance in current laws. They point out the existing flaws in the system used in Iran and suggest a few ways for improving it.
\end{abstract}

Keywords: legislation, uniform emission standard, water quality objective standard, water pollution in Iran.

\section{Introduction}

Adequate legislation is the primary requirement for the control of surface and ground water pollution and related organizations must enforce and administer the law. However, depending on factors such as the legal system, degree of development, climate and the traditions of a country, the type of organisation may differ from one country to another (Ellis [4]). A very important point to note is that adequate legislation without effective administration is not constructive. Independence of any such organization is necessary and the administrator should 
have freedom to operate according to the clauses in the legal guidelines. In general, the main tasks of any organisation undertaking water pollution control are as follows:

1-0 Apro-active approach to prevent pollution arising by:

1-1 Legislation

1-2 Action on the ground.

2-0 Enforcement by prosecution "Stop-Notices" ordering work to be done. Generally, there are two philosophies regarding the surface water pollution. In the first approach, which is known as the Uniform Emission Standard (UES), a common quality standard is set for all river users without any regard for the dilution possibility or the existing quality of the receiving streams or their future uses.

The second approach called the Water Quality Objective (WQO) Standard, regards the present and future use of a river, which has an active role. Modern technology is used to assess the natural ability of the river, how it assimilates and, to varying degrees, provides self- purifying effluents without creating untoward deterioration effects. Each polluter is then advised accordingly on the level of the river pollution and the absorption level of that particular stretch of the river.

Between the above two philosophies, the first method is more commonly used, because of its easy use of operation. The second method seems to be more effective and accurate. However, a uniform emission standard does not permit the optimisation of the resources associated with a river system unless, in the unlikely event, of aiming for the best possible technology approach (Ellis [4]).

Legislation for surface and ground water pollution control has been practised for three decades in Iran but the enforcement has not been so effective. As a result, there have not been any serious improvements in surface and groundwater quality in Iran. It is obvious that comparing two laws in two different countries with different cultural views, technological background and social development is a very difficult task, but the author tried to find out the deficiency on the existing law and managment in Iran relating to that in England. The issue here focused on the ineffectiveness of the existing law, implementation and the ways to improve the existing situation.

\section{The provisions of law on water pollution control in Iran}

Apart from the North of Iran (near the Caspian Sea), the rest of the country has an arid or semi-arid hydrological climate. Due to the limited water resources, there is a serious water shortage especially in dry seasons. Therefore, protecting surface water and ground water aquifers is especially important. As the volume of the surface water is low, the capacity of the acceptable polluted water has also to be in a smaller volume in order to be suitable for the general well being of the people, this makes the protection even more critical. Furthermore, due to the special attention given to the industrialization of the country, the polluted water from industrial plants and agricultural lands should not be allowed to endanger the quality of the limited water resources. 
It seems that a brief explanation of how legislation is made in Iran and how it is operated is necessary, hence a short summary is provided below.

There are two common ways in which this can be done:

2.1 A minister or a director puts forward a motion regarding his own ministry or organisation to the cabinet. It is discussed in the cabinet and once it is approved by the majority, it is sent to parliament. The parliament refers the bill to the experts committee, whose duties at an early stage are to take an overall view and examine the bill. Once approved by this committee it is returned to the parliament to be voted on as a whole. It is once again returned to the experts committee to be examined in detail. After the experts committee approve the bill, it is forwarded for a second time to parliament to be voted on. When the majority of members pass the bill, it is then sent to the Guardian Council (a powerful council consisting of 6 religious experts and 6 law experts) to be examined as to whether it conforms to the constitution and Islamic laws or not. If there are no flaws in it, it is returned to the parliament to become law and finally is returned to the cabinet to be implemented.

2.2 Step two is rather similar to step one, the only difference is in the way the motion is put- forward. Fifteen or more members of parliament can approve the motion and the rest is exactly the same as step 1.

For the first time, in 1956, the Water Pollution Control under Article 12, section C, (Hunting and Fishing Act) was passed into law by the Parliament and amended in 1967. The Environmental Protection Law consists of 22 sections and nine provisions and was passed in 1974 some of them are as follows.

Section 1: Protection and improvement of environment and prevention of any pollution and any activity, which may cause an imbalance in environment, also all actions related to wild animals, are under the responsibility of the Departement of Environment (DOE). This is limited to the boundaries of the Iranian water system.

Section 2: The DOE is referred to as an organisation, which is directly answerable to the presidential office. It also has legal entity and is financially independent. The organisation functions under the DOE higher committee. The president of Iran is the head of the higher committee.

Section 5: Appointment of any person to hold office, as the chairman shall be made by the president of Iran.

The constitutional arrangement of the DOE is shown in Figure 1. Suggestion of the standards for prevention of pollution of water, air and soil and distribution of domestic and industrial solid waste and in general parameters which have adverse effects on the environment is the duty of the DOE, and also implementation of educational programmes for the promotion of public opinion for protection and improvement of environment is the duty of the DOE.

According to item 6 of the board approved guidance on prevention of water pollution regulation (1994), the DOE has been made responsible to monitor and classify all of the surface and groundwater, but they still use the Fixed Emission Standard method to control water pollution because there is not yet complete information and control upon all surface and ground water quality in order to establish the degree absorbency of pollution into these waters. 
Section 11: The DOE in accordance with regulations and codes of practice, relating to section ten, identify factories which cause pollution to Environment. All owners of the factories responsible for the pollution are given an enforcement notice with relevant reasons. They are then obliged to remove the pollution source in a specified period or stop their activities. Any person who fails to comply with any requirement imposed by an enforcement notice by the DOE is prevented from any other activities. If any person concerned questions the enforcement notices ordered by the DOE, they can appeal the case to the public court in that area. The court will then immediately study the case and if it finds any plaintiff they will immediately quash the enforcement notice and the plaintiff is allowed to continue normal activities. The decision of the court is final. For sources and parameters, which have imminent danger for the Environment, the chairman of the DOE has the right of stopping the activity of the polluter without any written notification.

Section 12: Owners, or the responsible persons in the factories and workshops, which were mentioned in section 11 , must stop their activities whenever they receive the order of the DOE. Continuation of work or activity depends on the permission of the DOE. If any person fails to comply with the order of the DOE or the decision of the relevant court, they may be sentenced to imprisonment from 61 days to one year or pay a fine.

Protection of seas and rivers at the boundaries of the country from any oil pollution is the duty of Road and Transportation Minstry. In this regards, there is a law which was passed in 1975 and it consists of nineteen sections and eight provisions. Some of the important sections are detailed below:

Section 2: "The pollution of rivers at the boundaries, internal waters and seas in Iran from oil or any oil based polluters, caused by ships, drilling platforms, artificial islands and from piping facilities, or oil resources in the sea or on the land are illegal. Any person polluting the water can be sentenced to jail from six months to two years and penalised to pay a fine.

Section 11: The enforcing authority for the above section is the Shipping and Harbour Organisation, which is under the supervision of Ministry of Roads and Transportation.

\section{Summary of the water pollution control legislation in England and Wales}

In the United Kingdom, most rivers are relatively small and therefore they can only accommodate limited amounts of pollutant load (Robinson [11]). Therefore, the main reason for the development of the water pollution control legislation in the UK, which was established before other industrial countries, such as the USA, was the decrease in river quality caused by the intensification of industrialisation during the Industrial Revolution and the resulting epidemic diseases associated with it. Early legislation was based on having regard to riparian rights. Land owners traditionally possess rights relating to the quality of the water in the rivers or streams and so on, which is received by the land owner 
in his section of that river or stream, under common law. The land owner may use the water, but cannot diminish its quality or quantity (Jenkins [5]).

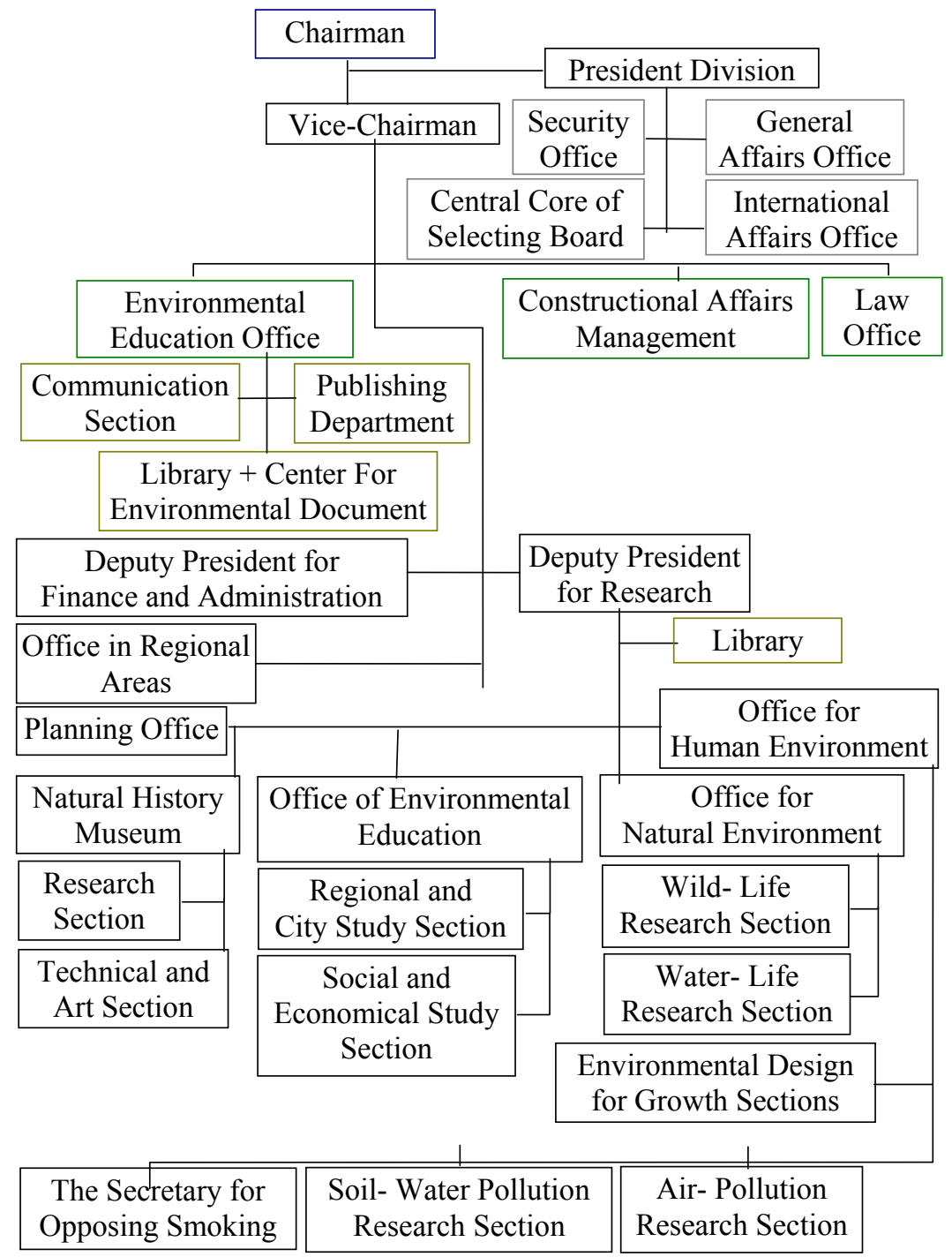

Figure 1: The constitutional chart representing the DOE in Iran (DOE, 1994).

In 1865 and 1868 the Royal Commission recommended the modern water pollution control legislation on rivers. The 1868 recommendation of this Commission regarded the standards of purity for effluent discharge into watercourses. The Royal Commission attempted to incorporate their recommendations on three occasions initially in 1872, then in 1873 and finally in 
1875. In none of these three attempts, was success achieved. In 1876, some of the Commission's recommendations were passed by Parliament. One of the Acts passed during this period was the River Pollution Prevention Act (1876). The Act is concerned with the control of sewage discharges into rivers from domestic and industrial sources. At that time, there were two factors which prevented suitable effective pollution control. The first factor was the division of responsibilities between the different authorities made responsible for different aspects by the Act, and the second one was the involvement of some personalities that made it difficult to operate. Despite these weaknesses, this River Pollution Control Act operated through the mid twentieth century (Ellis [4]).

The River Authorities were formed under the water resources Act 1963 in 1964, which empowered conservation, redistribution and proper use of water resources in their areas (Jenkins [5]). The Regional Water Authorities were formed under the water Act 1973, in 1974 and were responsible for the management of most aspects of the water cycle, except when the water supply was the responsibility of the statutory water companies, and when certain powers remained related in certain Government Ministers and agencies. These include water supply, wastewater treatment, and operations on the river catchment basis and finally the administration of legislation to control water pollution (Howarth [6]). Another Act on the control of pollution Act (COPA) 1974 was passed by the Parliament in 1974 which was a controlling act consisting of four parts as stated below

a) Control over solid wastes;

b) Control over water pollution; (to a limited extent)

c) Control over noise pollution; and

d) Control over air pollution.

Apart from item (b), others were largely implemented since 1976 (Doughty [2]]), but the implementation of part (b) was postponed to 1983. Most provisions came into force over the period of July 1984 to January 1985 (Matthews [8]). This Act replaced those of the rivers which were the Prevention of Pollution Act 1951 and 1961, Estuaries and Tidal Waters Act 1960 and the Water Resources Act 1963 (Matthews [8]). Between 1974 and 1989 the water industry in the UK was composed of ten Water Authorities which were responsible for water supply and sewerage services as well as several other water related responsibilities and 29 Statutory Water Companies (SWCs) that only provided water supply services. In the UK, about one third of consumers have received water supply services from the SWCs but received their sewerage services from one of the Water Authorities. The SWCs were subject to statutory controls on profits, dividends, borrowings and statutory limitations on the number of votes. The water and sewerage companies were formed by privatisation under the same regulatory framework. The water bill was making its way through parliament after the passing of the Water Act 1989. In April 1990, England and Wales's ten water and sewerage companies were privatised. Both abstraction of water from rivers and aquifers, and discharges of unclean water to clean water-courses were controlled by the National River Authority 
which has now been replaced by the Environment Agency. Office of Water Service (OFWAT) is not a government department but an independent body which is set up to implement and administer the responsibilities of the Director General of Water Services, as provided for in the water Act 1989 (Macrory [9]). OFWAT is also a watchdog body, whose mandate is to protect the interests of the customers of the privatised water and sewerage companies efficiently. It also controls prices charged to customers and aims to ensure that the companies operate effectively (Croner's Environmental Management, 1991). OFWAT operates through its central headquarters (based in Birmingham) and it has other offices in eight other cities through England and Wales. Its main tasks are as follows:

a) control of prices;

b) standard of service; and

c) consumer protection:

In England and Wales, regulation of quality has been tackled by subjecting water companies to a wide range of quality regulations and constraints. These include:

i) drinking water quality regulations;

ii) pollution controls;

iii) customer service standards; and

iv) customer service standards, which include codes of practice, and are monitored by OFWAT.

The legal controls over the pollution of water were provided under part III of the Water Resources Act (1991) which came into force in December 1991. According to section 84 of this Act the following should be considered.

1) It shall be the duty of the Secretary of State and of the [Agency] to exercise the powers conferred on him or it by or under the water pollution provisions of this Act [other than the preceding provisions of Chapter one (Quality Objectives of Water Resources Act (1991) and sections 104 and 192 the chapter] in such manner as ensures, so far as it is practicable by the exercise of those powers to do so, that the water quality objectives specified for any waters in

a) a notice under section 83 of this chapter; or

b) are achieved at all times

2) It shall be the duty of the [Agency], for the purposes of the carrying out of its functions under the water pollutions of this Act-

a) to monitor the extent of pollution in controlled waters; and

b) to consult, in such cases as it may consider appropriate, with river purification authorities in Scotland (Duxbury and Morton 2000)

The NRA was responsible for monitoring, controlling and seeking to prevent pollution discharges (Howarth [7]). It had the power to prosecute dischargers who had committed an offence. Under section 85 of the Water Resource Act 1991, it is an offence to cause or knowingly permit the following acts:

a) discharge of poisonous, noxious or polluting matter, or any solid waste matter to entre any controlled waters;

b) discharge of matters other than trade or sewage effluent, to enter controlled waters by being discharged from a drain or sewer;

c) trade or sewage effluent to be discharged: 
i) Into any controlled waters; or

ii) from land in England or Wales, through a pipe, into the sea outside the seaward limits of the controlled waters.

d) Trade or sewage effluent to be discharged from a building or from any fixed plant or into any land, or into any waters of a lake or pond which are not inland fresh waters; and

e) any matter which enters any inland fresh waters so as to tend either directly or in combination with other matters which or another person to impede the proffer flow of the waters in a manner leading, or causes or permits to enter those waters and is likely to lead to a substantial aggravation of

i) pollution due to other causes or

ii) the consequences of such pollution (Duxbury and Morton [3]).

The Environment Act (1995) consists of 218 sections and 24 schedules. According to this law implementation of some chapters and sections of the water industry 1991, water resources 1991, Water Act 1989 and some other parts of Acts relating to protection of environment are under the control of an integrated duty called the Environment Agency (the EA). The National Rivers Authority and the London Water Regulation Authority are abolished (Duxbury and Morton [3]).

\section{Comparison of current water pollution legislation of Iran with England and Wales}

There are some similarities and differences apparent in the two systems which can be seen in Tables 1 and 2. The comparison made between the two systems is reached through a detailed study of different sections and provisions of the two laws. Some of the similarities and differences are as follow:

In section 110 (1) of Environment Act 1995, the EA support any authorized person who would perform his power or duties in accordance with this section but in Iranian Environmental protection law, there is no such section which would support any authorised person to exercise his powers or duties in Iranian law.

Table 1: Principal system for control of water pollution in Iran.

\section{Principal Act}

Hunting and Fishing Act 1956

Hunting and Fishing amendment Act

1967

Protection and improvement of

Environment Act 1974

Protection and improvement of

Environment amendment Act 1991

Protection of seas and rivers at the boundaries from oil pollution Act 1975

$\begin{array}{ll}\text { The relevant ministries } & \begin{array}{l}\text { Enforcing } \\ \text { authorities }\end{array} \\ \begin{array}{l}\text { The president of Iran } \\ \text { The president of Iran }\end{array} & \begin{array}{l}\text { The DOE } \\ \text { The DOE }\end{array} \\ \text { The president of Iran } & \text { The DOE } \\ \text { The president of Iran } & \text { The DOE } \\ \begin{array}{ll}\text { Minster of Road and } \\ \text { Transport }\end{array} & \begin{array}{l}\text { The Harbours } \\ \text { and Shipping } \\ \text { Organisation }\end{array}\end{array}$


Table 2: $\quad$ Principal system for control of water pollution in England and Wales.

\section{Principal Act}

The Control of Pollution Act 1974

The Control of Pollution Act 1989

(Amendment)

The Water Act 1989

The Water resource Act 1991

The Water Industry Act 1991

The Environment Act 1995

The Pollution prevention and control Act 1999

\section{The relevant ministries}

The Secretary of State

The Secretary of State

The Secretary of State

The Secretary of State

The Secretary of State

The Secretary of State

The Secretary of State

\section{Enforcing authorities}

The EA

The EA

The EA (some

sections)

The EA (some

parts)

The EA (some

sections)

The EA

The EA

According to section 82 and 83 of Water Resources Act 1991, the EA classifies the quality of water and determines the objective of using the controlled water and comprehensive effluent standards, environment quality standards and action plan for preventation of pollution but at present the DOE only exercise Fixed Emission Standard (DOE [10]) that is not effective. Having Environment Quality Standard needs a complete network of sampling sites and analysing collecting data.

The Ministry of Roads and Transportation and the enforcement authority in the Shipping and Harbour Organization is responsible for oil pollution. Hence, there is not an integrated management system in control of water pollutoion in Iran.

Regarding section 108 of Environment Act (1995), which is called the powers of enforcing authorities and persons authorised by them, there are 16 subsections. According to the section any authorised person by the EA at any reasonable time (or, in an emergency, at any time and if need be, by force), can inspect any premises which he has reason to believe it is necessary for him to enter; or if there is any serious pollution to environment authorised person can enter to the place for examination or checking (Duxbury and Morton [3]). But in the Iranian Law if the authorised person from the DOE wants to enter the place for checking the level of pollution, the owner can prevent the entry, unless the authorised person has permission from the public prosecutor's office. This causes delay in stopping the source of pollution.

The comparison made so far between the legislation of the two countries has only been detailed information between sections and provisions of the two laws, so more practical real life situations are as follow.

- England has several centuries of historical institutional developments; the Islamic republic of Iran has relatively short history of political evolution, which has experienced very drastic changes.

- England has a nationwide common effluent regulatory standard and water specific pollution control actions to attain target ambient water quality while Iran 
has a fixed emission standard which is not appropriate and effective for all part of the country.

- According to Environmental Law (DOE [10]), establishing any types of development project (Economic, Industrially, etc), government and private sectors must consider protection of the environment, but in practice priority of development is more significant than environment protection

- Public is not aware of the significance of the protection of the environment, even sometimes in a judiciary system, despite the existing law for the protection of the environment, courts don't issue reasonable judgement for the people that don't comply with the legislation and regulation.

- Implementing laws needs sufficient tools, appropriate technology, human recourses, institutional capability and contribution and interaction between related ministries such as the Ministries of Industry, Power and Jihad-agriculture, which England has, but the DOE does not have the appropriate capabilities.

Recently there is closer contribution and interaction among the DOE and mentioned ministries, but as mentioned previously agricultural and industrial developments are the priorities in Iran. Therefore the following are suggested as first steps:

1-It is necessary to strengthen the capacity of the DOE in order to implement the water quality monitoring, the environmental impact assessment for the new developed industrial and agricultural sectors and executing laws, regulations and standards in all part of the country.

2-Close cooperation and interaction between the DOE and the related ministries is necessary to improve waterquality.

3-To design a timetable for the polluters (both governmental and private sector) in which they can reach the effluent to a standard level with a step-by-step programme.

4-Public awareness and environmental situation should be one of the main projects implemented in Iran through the close cooperation with media and NGO.

It is quite a good aim to strengthen the capacity of the DOE. This requires a huge budget and human resources, proper technology, and suitable institutional organization. Of course this project can be carried out as a pilot project in a limited area and if the result is successful, then it may be extended and duplicated in other parts of the country.

\section{Conclusion}

As a whole the existing water pollution law in Iran needs reviewing and may also require amending in order to reach the standards that will tackle the environmental pollution issues.

In comparisons made between the legislation of England and Wales and Iran regarding water pollution the following points may be necessary in improving the current law and Management of the Iranian system.

-Political will is the most important element; it can help improve the implementing of the legislation and environmental situation. 
-To strengthen capacity of the DOE (human resource, technology, institutional organization, etc) so that the DOE will be able to enforce the law properly. -Cooperation and interaction between the DOE, Minstry of Housing, Ministry of Culture, Ministry of Education, Radio and Television Organization and Private sectors is vital.

-Public awareness and education are other elements which need a master plan study and greater effort. The subsection regarding public awareness needs to be expanded and explained more thoroughly and also the public training needs to be more widespread using mass media.

-The current control of water pollution lies with the DOE and the Ministry of Road and Transportation. It seems that if it was possible to give the control to one organisation (the DoE) it would improve the management of the water pollution.

-To strengthen the DOE in all parts of the country for implementing water quality monitoring and analysing data, so the results of interpretation of data can help decision makers to make a suitable decision for reduction of water pollution, and it can help for the development of local standards.

-The offence section of the law needs to be more vivid and more detailed in order to make aware the offenders so that they can be punished accordingly; this will also help greatly the management of the water pollution.

-There is no legal position for Non-governmental Organisations. It is suggested to add a section relating to NGO to Iranian water pollution legislation.

-It would be necessary to review effluent standards and to prepare comprehensive environment quality standards for watercourses. The environment quality standards should be set for the receiving watercourse and not the discharge itself.

\section{References}

[1] Croner's Environmental Management "Water Pollution Control and Water Supply" Kingston upon Thames: Croner, October, (1991).

[2] Doughty, G. M. COPA: “An Act of Remembrance?" The Public Health Engineer. 10, 178- 179, (1982).

[3] Duxbury, R. M. C. \& Morton, S. G. C. “Blackston's Statues on Environmental Law" Blackstone, London, U.K., Third Edition, (2000).

[4] Ellis, K. V. "Surface Water Pollution and its Control" Houndmills, Macmillan, UK, (1989).

[5] Jenkins, W. O. "Decision Support System in River Basin Management" PhD Thesis, Imperial College, University of London, (1988).

[6] Howarth W. "Water Pollution Law" show and sons, London, UK, (1988).

[7] Howarth W. "The Law of the National Rivers Authority" The National Rivers Authority and the Centre for Law in Rural Areas, University College of Wales, Aberystwyth, (1990).

[8] Matthews, P. J. COPA II: "Interpretation and Application" The Public Health Engineer, 14, 38-42, (1987).

[9] Macrory R. "Water Act" Sweet and Maxwell, London, (1989). 
[10] The Department of Environment "Laws and regulations relating to protection of Environment" The DOE, (in Farsi), (2000).

[11] Robinson, R. "The Control of Pollution Act 1974. Implication for River Quality Management" Journal of Institute of Water Engineering and Scientists, 34(2), 129-144, (1980). 